\title{
HOUSE FINCH AT ABERNETHY IN 1990
}

RONALD A. BITTNER, Box 97, Abernethy, Saskatchewan. SOA OAO

The date was 3 June 1990 and the time was mid-afternoon. As I walked around the end of the house I heard an unexpected bird song. I looked up and saw a red, sparrow-sized bird on a wire between the house and a utility pole. After about five seconds the bird flew across the street into some trees and disappeared from view. Based on this brief observation from a distance of $30 \mathrm{ft}$., I assumed that the bird was a Purple Finch.

I was surprised to see a Purple Finch in June. Almost all my sightings have been during spring migration. A recent review of my notes from 1983 to 1993 shows that Purple Finches were sighted on 28 separate days ranging from 12 April to 7 May. There were only three sightings outside this range: 13 May 1990, 10 July 1983 and 2 October 1983.

I went back into the house assuming that 1 would not see this bird again. A few minutes later I looked out the window and saw a red bird almost certainly the same one - on our hanging feeder in the back yard. This time I was able to get a much better look at it. I observed with binoculars from a distance of $20 \mathrm{ft}$., first from in the house and then outside. The bird did not seem to be unduly alarmed when I went outside.

Compared to a male Purple Finch this bird seemed slightly smaller and slimmer. While the Purple Finch is more or less all red, this bird might be better described as a brown bird with red patches. The red was confined to forehead, eye line, rump, throat and upper breast. The lower breast and flanks were whitish and streaked with brown, quite different than the relatively unmarked underparts of the male Purple Finch. The shade of red needed no qualifying, it was simply bright red. The Purple Finch is often described as rose or wine coloured.

After studying the bird for five minutes I went back into the house and took a quick look at my bird guides. ${ }^{1,2,3,4}$ It was quite obvious that this bird was a House Finch. I got the camera, hoping that the bird would come to our window shelf feeder. It did, and I took the first photo from a distance of $5 \mathrm{ft}$. The bird has a sunflower seed in its beak. It left the shelf for a moment, and I moved closer to the window hoping to get a better picture. The bird returned, and the second photo was taken from 3 $\mathrm{ft}$. away. The pictures were taken with a 50-mm lens and Kodachrome 64 film. The bird spent a total of about 15 minutes in our yard and was not seen again.

As a footnote to this story, I saw what I think was a female House Finch at our hanging feeder on 6 April 1993. Compared to a female 
Purple Finch this bird seemed smaller, and the streaking was less distinct. The face lacked the strong pattern of the female Purple Finch. The bill was stout, unlike the thinner bill of the Pine Siskin. This bird stayed for a few minutes and was not seen again.

1. GODFREY, W.E. 1986. The birds of Canada. National Museum of Canada, Ottawa. 595 pp.
2. PETERSON, R.T. 1961. A field guide to western birds. Houghton Mifflin, Boston. 366 pp.

3. ROBBINS, C.S., B. BRUUN and H.S. ZIM. 1966. Birds of North America. Golden Press, New York. 340 pp.

4. SCOTT, S.L., ed. 1987. Field guide to the birds of North America. National Geographic Society, Washington, D.C. 464 pp.

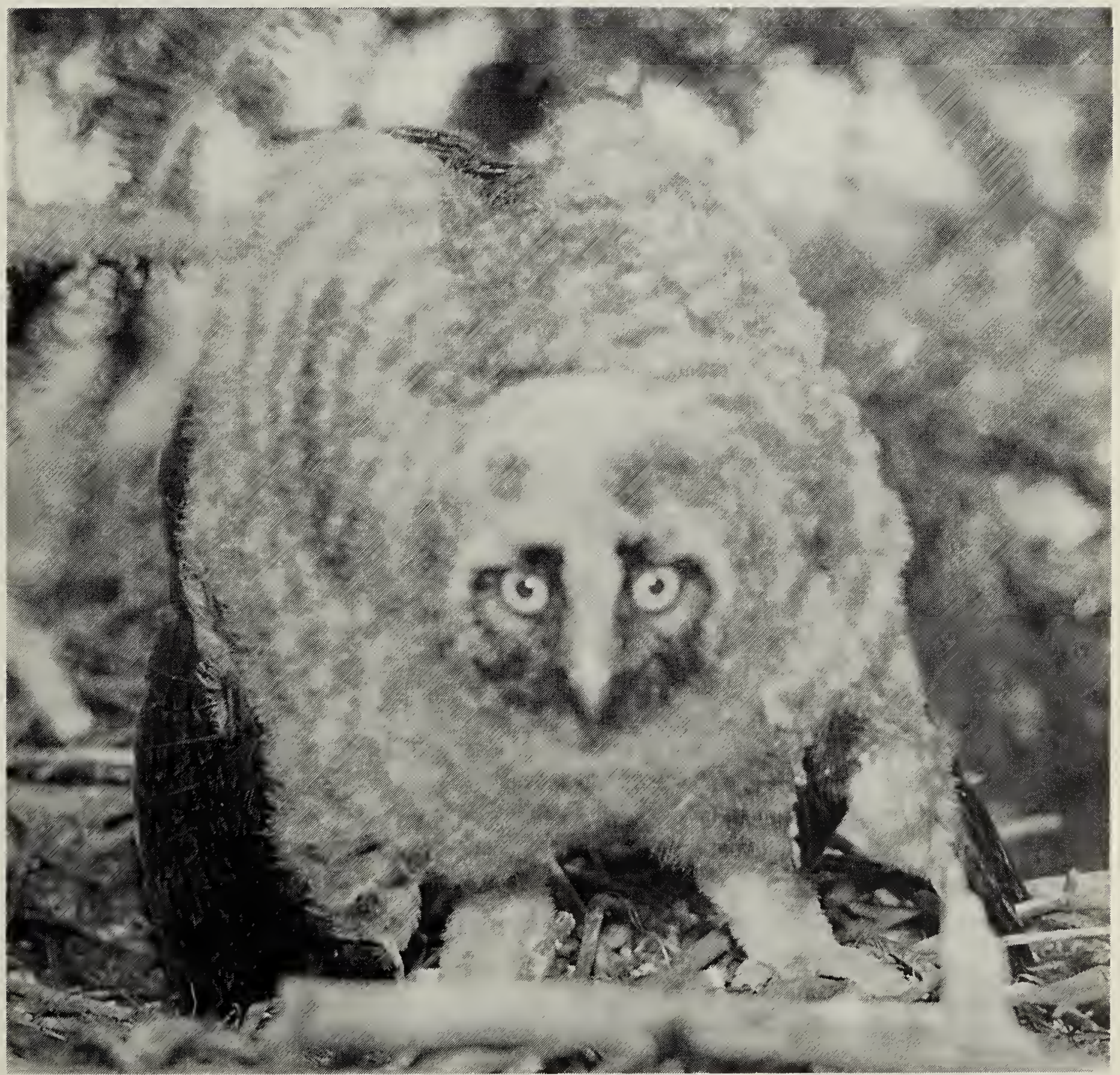

